Article

\title{
The Hanging Garlands of Pompeii: Mimetic Acts of Ancient Lived Religion
}

\author{
Dylan Rogers $\mathbb{D}$
}

McIntire Department of Art, University of Virginia, Charlottesville, VA 22903, USA; dkr5t@virginia.edu

Received: 29 March 2020; Accepted: 19 May 2020; Published: 26 May 2020

check for updates

\begin{abstract}
Roman painting is full of items associated with religious practice. Garlands, in particular, are found represented in Roman frescoes, often draped over different panels to enliven the painted surface with the semblance of abundant fresh flowers. There are indications, however, that in Roman domestic spaces, latrines, and streets, physical garlands were actually attached to the frescoes as votive offerings that mimic the painted garlands behind them. This paper considers how Roman paintings worked in tandem with garlands and other physical objects, and how Pompeiians engaged in mimetic acts. The two-dimensional painted surface depicting "mimetic votives" should be viewed within a three-dimensional space inhabited by people and objects. The mimetic act of hanging a garland was part of ancient lived religion, and, as such, enables us to examine past religious experiences, focusing on the individual and communication with the divine. The relationship between these various visual media would have created unique experiences in the daily lives of ancient Romans that are rarely considered today.
\end{abstract}

Keywords: Roman painting; Roman religion; Pompeii; lived religion; lares; garlands; ancient daily life; mimetic acts

\section{Introduction}

Roman wall paintings provide us with intimate glimpses into the daily life of the ancient Romans. From domestic interiors to street corners, the decorated surfaces of Pompeii, in particular, offer insight into the shared experiences of the inhabitants of that city, especially through scenes with religious subjects. Of particular interest to the present article are paintings that indicate religious practices that once took place in the spaces of those paintings. In scenes that represent religious activity, such as sacrifices associated with the lares, we can see a variety of religious paraphernalia, from altars, sacrificial victims, attendants, divinities, and floral decorations. Many of these scenes are draped with vibrant floral garlands, which signify the actual garlands that were offered by the Pompeiians performing religious rituals. Moreover, there are indications of nails, and holes for nails, on numerous frescoes from Pompeii, suggesting that garlands were attached to the surfaces overlaying their painted counterparts-a situation creating a visual and material interplay between the physical object and its painted representation. The two-dimensional painted surface depicting "mimetic votives" should be viewed within a three-dimensional space inhabited by people and objects. ${ }^{1}$ These spaces then invited individuals to perform the mimetic act of hanging a votive garland. Thus, the relationship between these various visual media would have created unique experiences for ancient viewers that are rarely considered today.

In order to understand better how these painted surfaces displayed physical objects and provided an interactive canvas for the people attaching them to the wall, we will consider the evidence of the

1 On the mimetic votive, see: (Elsner 2007, pp. 42-45), along with the discussion below. 
lived religion of the Romans. The approach of lived religion allows us to question how an ancient individual used space and practiced religious rites in a variety of contexts, thus bridging the gap between two-dimensional surfaces with the three-dimensional spatial experiences. ${ }^{2}$ Then, we will examine the evidence of floral dedications of the Romans, using literary and archaeological sources, including the nails used for hanging garlands at Pompeii, paying close attention to painted surfaces with religious imagery. The preliminary observations made here can aid our understanding of everyday religious practices throughout the Roman world.

\section{Lived Religion and Painted Religious Scenes in Pompeii}

Recently in the study of Roman religion, an approach termed 'lived religion' has been developed, which allows scholars to reconsider the actions of ancient worshippers, in order to reconstruct daily devotional activities. ${ }^{3}$ There are important points that arise from the concept of lived religion in the ancient world. First, communication between humans and the divine drives, in part, religious practice. It is the desire for humans to talk directly with the gods, and to curry their favor, that produces evidence of religious activity in material culture. Indeed, it has been noted that "objects form part of the ongoing sacralization of [ ... ] spaces," which follows in our discussion of the relationship between painted surfaces and the attached objects as part of everyday religious practice in Pompeii (Albrecht et al. 2018, p. 572). Second, the role of the individual in ancient religion is of the utmost importance (Belayche 2007, p. 276). For example, Molly Swetnam-Burland has demonstrated the relationship between individuals and religious practice in private examples of Isiac cults in Pompeii. Graffiti on painted surfaces related to the cult of Isis indicates the ancient worshippers' understanding of the gifts they offered, along with "reflect[ing] the everyday language and informal speech acts" of these individuals (Swetnam-Burland 2018, p. 591). Since religion is not monolithic, but rather dynamic, it allows for numerous unique expressions of religious devotion that we can recognize in the archaeological record.

In lived religion, there are a number of ways to discern religious activities that can suggest past actions. While there are written and oral religious acts, which do not always survive or are ephemeral, the pictorial act is a more permanent form of religious devotion in the material record (Weiss 2015a, pp. 66-68). The pictorial act in religious devotion is the representation of offerings given by human agents for the divine. The permanency of illustrated offerings has the ability to act as actual offerings for the gods, even when religious devotion is not being practiced in those spaces by humans-in effect acting as mimetic votives (Elsner 2007, pp. 42-45; Weiss 2015a, p. 67). Indeed, the second-century CE travel writer, Pausanias, described a similar mimetic act at Delphi (10.18.5). The Orneatai vowed to Apollo that they will perform a daily procession if he drives out the Sikyonians, who were ravaging their lands. When the Orneatai were victorious, they dedicated a bronze statue group of a sacrifice and procession at Delphi. In this instance, the representation of the procession fulfills the vow as a mimetic votive, and the permanency of the statuary allows, in a sense, an eternal procession in Delphi. The pictorial act and mimetic votive can then promote future religious devotion, as the "use of objects or the modification of an environment that instantiates religion either directly or by physically commemorating religious experiences and practices, thus creating the infrastructure for further religious action by others" (Albrecht et al. 2018, p. 580). Such pictorial acts and mimetic votives have the potential to suggest perpetuated action, which insinuates that religious activities occurred numerous times around these images (Weiss 2015a, 2015b). As we will discuss below, the painted hanging garlands and the nails used to support them are vestiges of lived religious practice in Pompeii

2 There are also examples of similar pictorial acts of offering floral garlands in Buddhist art. For example, on a volute of a winged deity from Pakistan from the early Kushan period (first century CE), the deity holds a garland; however, it is believed that the volute itself would have allowed individuals to hang physical garlands on it, too. In addition, at the Great Stupa at Sanchi, a relief shows human and divine beings adorning the structure with garlands, in addition to having hooks to allow for the addition of physical garlands by pilgrims visiting the stupa. For more, see: (Lerner and Kossak 1991, p. 72).

3 For overviews of the approach of ancient lived religion, see: (Rüpke 2011; Raja and Rüpke 2015; Rüpke 2015; Rüpke and Degelmann 2015; Albrecht et al. 2018; Gasparini et al. 2020). 
by human agents, motivating individual devotional acts in these spaces and thus communication with the divine.

At the site of Pompeii in Campania (Italy), there is ample evidence to allow for the study of ancient Roman religious life, especially the activity of individual agents outside of monumental expressions of religious practice. ${ }^{4}$ The primary evidence for religious devotion, especially in terms of the pictorial act, comes from painted surfaces that depict gods, altars, attendant sacrificial personnel, and shrines, which are explored more fully below. ${ }^{5}$ Secondary evidence of religious activity can come from other types of artifacts, including sculpture, lamps, wall niches, and silver or tableware (Kaufmann-Heinimann 2007, pp. 192-97; Rüpke 2018, pp. 255-61). ${ }^{6}$ There are also indications based on the location of paintings or shrines that can shed light on who might have been performing religious activities in a given space. For example, it is argued that painted shrines found in the atrium of a home were attended by the paterfamilias and perhaps members of his immediate family, while examples found in kitchens were used by the slaves using those areas of the home (e.g., Kaufmann-Heinimann 2007, p. 199; Flower 2017, pp. 46-48). ${ }^{7}$ Further, a painted shrine at a crossroad was evidently used by not only the associated magistrates of that cult, but also inhabitants of that neighborhood, who interacted with the shrine presumably on a daily basis and not just during certain festivals (Hartnett 2017, pp. 263-69).

One of the most common depictions of religious devotion found in Pompeii is related to the worship of the lares. There is a great deal of scholarly debate, both in antiquity and today, on the nature of these deities; however, it is generally agreed that the lares, who permeated nearly every part of Roman life, were guardian figures associated with a place (Flower 2017, pp. 2-5). ${ }^{8}$ The painted shrines associated with the lares have come to be called lararia in modern scholarship. ${ }^{9}$ Lararia in Pompeii included a variety of elements, including paintings, niches, aedicules, and altars (either permanent or portable). Arguably, one of the most identifiable aspects of a typical lararium is its painted iconography (Figure 1; LIMC 6.205-12; Fröhlich 1991, pp. 120-25; Giacobello 2008, pp. 89-110; Flower 2017, pp. 46-75). Traditionally, in the center of a scene, the genius (the protective spirit of the paterfamilias), holding a cornucopia, approaches an altar to offer a libation. Oftentimes, he is accompanied by attendants holding the necessary items for a sacrifice, including a sacrificial animal, garlands, an offering tray, and flutes. Flanking the scene are usually two figures identified as lares, who are dressed in short tunics, holding upraised rhyta that allow wine to flow into situlae, or pails, below; their jovial posture is often described as a dancing pose. These types of scenes are often accompanied by two large snakes that approach another altar, and they are often framed at the top by illustrations of hanging floral garlands.

Apart from lararia, there are other painted scenes that may have invited religious devotion. Within domestic spaces at Pompeii, numerous deities appear, including Bacchus, Fortuna, Hercules, Juno, Jupiter, Mars, Mercury, Minerva, Priapus, Venus, Vesta, Vulcan, river gods, and nymphs (Fröhlich 1991, pp. 129-54). These divine images had the potential to connect domestic religious activity

4 For example, see: (Laforge 2009; Van Andriga 2009; Bassani 2008; Bassani and Ghedini 2011; Bowes 2015). See also: (Barnabei 2007; D’Alessio 2009). We will not be concerned here with examples of public temples.

5 Here, we discard painted surfaces that depict mythological scenes as evidence of religious activities in domestic spaces in particular (e.g., Kaufmann-Heinimann 2007, pp. 189-91).

6 Sometimes these artifacts are not found in situ, which can prove to be problematic for interpretations of how they were used in their original contexts (Bowes 2015).

7 For more on the associations between the kitchen and religious activities of slaves there, see: (Fröhlich 1991; Foss 1997; Giacobello 2008, pp. 89-126; Bowes 2015, p. 213).

8 There has been a great deal written about the multi-faceted cult of the lares in Roman religion. The most recent and comprehensive treatment is Flower 2017. There is still discussion in modern scholarship on the differences between the lares and the penates, the former of which were tied to the heath of the home and the latter of which were deities tied by blood to the family. For the purposes of this article, the designation lares will be used. For more on this debate, see: (Fröhlich 1991, pp. 37-48; Laforge 2009, pp. 84-86; Flower 2017, pp. 46-52; Rüpke 2018, pp. 253-55).

9 The literature on lararia is vast: (Boyce 1937; Orr 1978; Fröhlich 1991; Bassani 2008; Giacobello 2008; Laforge 2009, pp. 47-77; Van Andriga 2009, pp. 217-69; Bassani 2017; Flower 2017). For discussions on the term lararium, see: (Bassani 2008, pp. 61-62; Giacobello 2008, pp. 54-58; Laforge 2009, pp. 19-47). 
to wider cult practices. For example, Hercules, Venus, and Mercury were popular deities in Pompeii. Hercules was himself tied to the city's initial foundation, Venus was the city's patron, and Mercury had a connection to commerce and Pompeii's role as a commercial port (Hartnett 2017, p. 268; MacRae 2019).

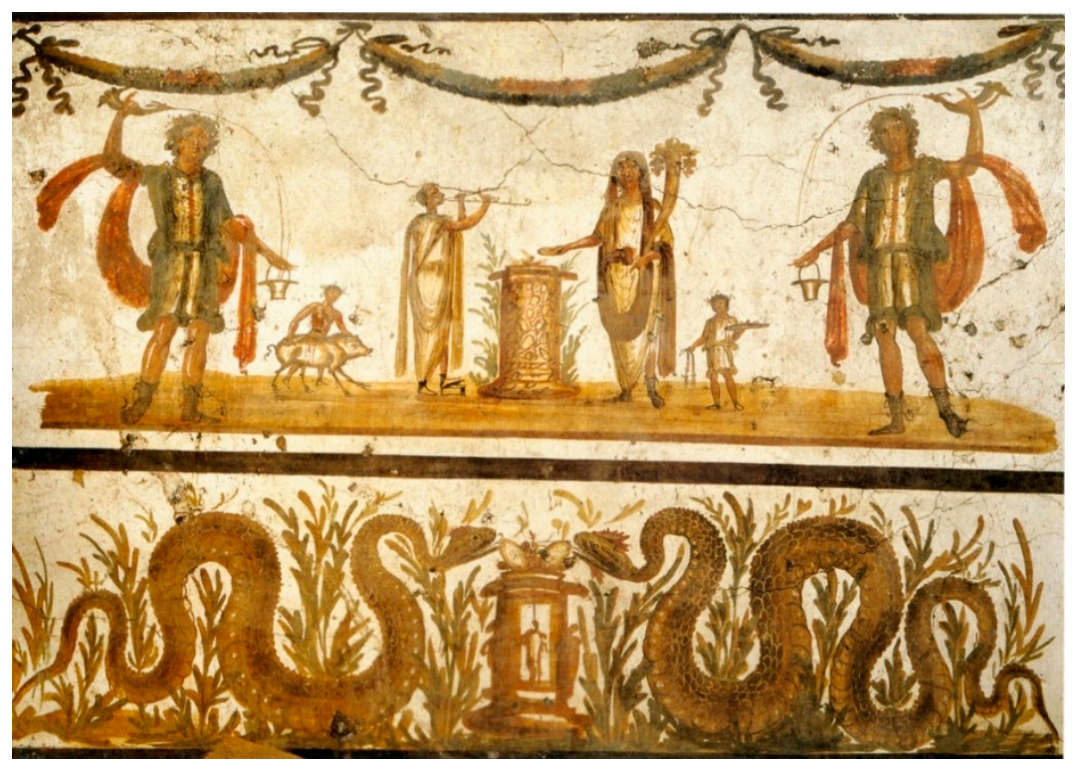

Figure 1. Wall-painting of lares flanking a sacrificial scene led by a genius, and three attendants (including one holding a garland on the right), atop two snakes approaching a circular altar. Naples Archaeological Museum, Inv. 8905. (Modified by author, after Fröhlich 1991, Taf. 10.2).

Outside of the home, illustrations of deities were seen throughout the city, often tied to the protection they afforded those spaces and the activities taking place there. On street façades, it is not uncommon to find groups of the 12 canonical gods of the Greco-Roman pantheon, tied to the dei consentes, the council of gods that oversaw human activities (Hartnett 2017, pp. 267-68). In shops or on façades connected to retail spaces, we find numerous depictions of Bacchus, Minerva, Fortuna, Mercury, Venus, and Hercules (Boyce 1937, pp. 110-11; Laforge 2009, pp. 86-93). In addition to the local connections that some of those deities had with Pompeii, some are also patrons of commerce, such as Fortuna, Mercury, and Hercules, which make them the ideal divinities to appear in commercial spaces-watching over the retail activities taking place there. Interestingly, we also find divinities on the walls of latrines, especially Fortuna (Jansen 2011, pp. 167-70; Koloski-Ostrow 2015, pp. 112-14; Rogers 2018, pp. 43-44). It is argued that the presence of Fortuna in latrines aided users for a variety of reasons, from good health or a successful bowel movement to leaving the toilet without encountering varmints who inhabited the drains (Koloski-Ostrow 2015, p. 114).

\section{Flower Garlands in Roman Religion}

Garlands, and also crowns, made from vegetation in the Roman world took many forms and were used for a variety of purposes. The Latin words for garlands (serta, corolla) and crowns (corona) often had fluid meanings, as was the case with many Latin expressions. As a result, we must use a specific context to know if an author refers to a garland or a crown. ${ }^{10}$ Garlands in particular were known by the Romans to have been made from flowers bound together; hence their Latin name, serta, derives from serere, the Latin verb for binding (Pliny, Naturalis historia 21.2). Garlands and crowns were either made from leaves (e.g., ivy, pine, poplar, laurel, myrtle, reeds) or flowers (e.g., roses, violets,

10 Pliny, Naturalis historia 21.1.2. For discussions of the Latin terms, see: (Guillaume-Coirier 1995, 1999). See also the later third-century treatise by Tertullian (De corona militis). 
oleander) (Pliny, Naturalis historia 21.27). Both garlands and crowns were used for religious dedications, personal adornment, or military victory; for example, recall Augustus being allowed to decorate his door with the corona civica, made from oak leaves. ${ }^{11}$

Roman garlands were made in a variety of ways. Pliny the Elder, in his discussion of garland flower types, states that he does not want to address garland construction (Pliny, Naturalis historia 21.9). Germaine Guillaume-Coirier uses both literary and artistic evidence to reconstruct how Romans garlands were made, classifying garlands and crowns into three types: (1) crowns; (2) loose hanging garlands; and (3) garlands constructed with reinforced frames using other vegetal materials (Guillaume-Coirier 1999, pp. 344-46; Guillaume-Coirier 2002). The construction of the second type is often depicted on the walls of Pompeii, with cupids collecting flowers, then working to incorporate them into flowing strings that are suspended from hooks on the ceiling (Figure 2 ). ${ }^{12}$ We should imagine that this type of garland is the mollis serta, a coiled garland, which allows for easy movement and flexibility when hanging the garlands (Guillaume-Coirier 1999, pp. 357-58).

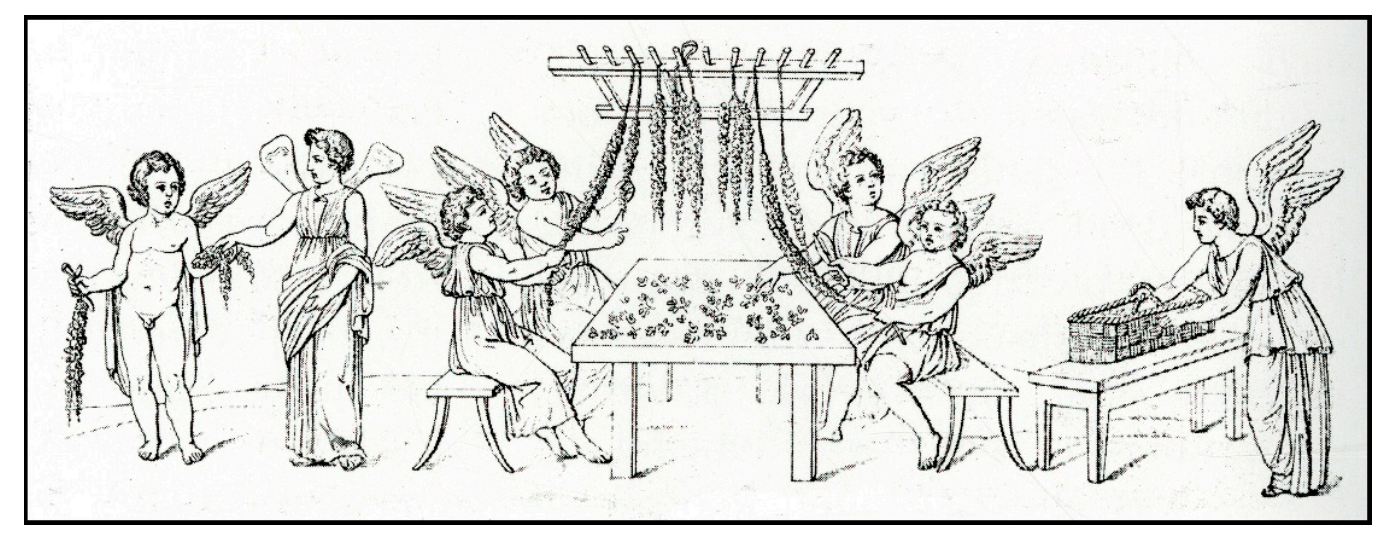

Figure 2. Flower dealer fresco (7.9.7). Pompeii. Cupids making garlands in the center. (Modified by author, after Jashemski 2018, Figure 4.23A).

It is assumed that the flowers used in garlands included roses, lilies, and violets (Guillaume-Coirier 1999, pp. 341-42). Rose garlands are often identified by their four or five petal designs, or their arrangement as a collection of what appears to be ball-like shapes, the latter of which is often seen on stone sarcophagi (Figure 3). Pliny himself asserts that most Romans use these flowers for garland construction because of the ease of finding them in their own gardens (Pliny, Naturalis historia 21.10.14). There is also evidence of commercial flower gardens in Pompeii, suggesting that there was certainly a market for flowers to be purchased (Jashemski 2018, pp. 143-51). An inscription found near the Sacred Way in Rome, in close proximity to monuments that received constant religious veneration, indicates that flowers and garlands could be purchased there (CIL 6.9283). As we will see, however, with the painted garlands in Pompeii in spaces associated with religious devotion, it is difficult to determine the variety of flowers actually being represented. Indeed, Pliny states that the painter cannot capture the true colors and combinations of colors of painted garlands, which would allow us to discern the varieties of flower types in Pompeii (Pliny, Naturalis historia 21.1.2). Regardless of the flower types suitable for the painted walls of Pompeii, these images served as vibrant reminders of the religious devotion taking place in those spaces.

11 Augustus, Res gestae 34. Pliny also describes some of the contexts for wearing crowns (Naturalis historia 21.2). See also: (Guillaume-Coirier 1999, p. 332). For more on the Roman uses of garlands, in addition to Greek and Etruscan, see: (Honroth 1971; Turcan 1971, pp. 108-33; ThesCRA 2.451-6).

12 For more on the iconographic evidence for the construction of these garlands, see: (Guillaume-Coirier 1995, pp. 1108-51). 


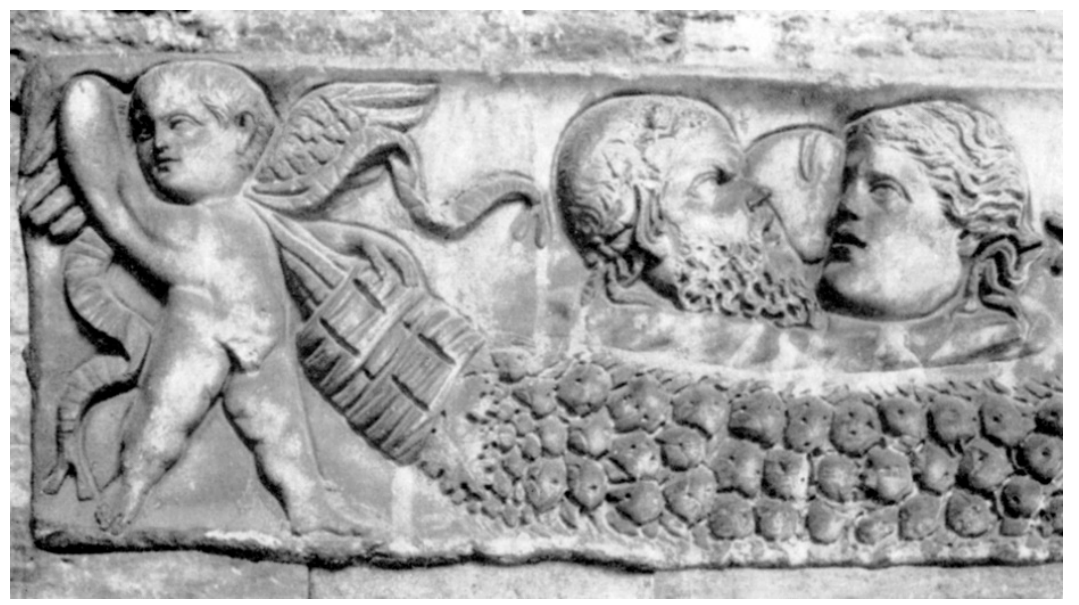

Figure 3. Sarcophagus with rose garland. Later third century CE. Rome, Terme di Diocleziano National Museum Inv. 124706. (Modified by author, after Honroth 1971, Taf. 12.2).

In terms of religious contexts, the act of giving floral garlands was an important element in the worship of deities of the Roman pantheon. Of interest here are the dedications of garlands associated with the lares. We know from literary sources that among the offerings given to the lares at the hearth (including incense, wine, and cakes), garlands were significant gifts. In the third to second-century $\mathrm{BCE}$ comedies of Plautus, we learn that the lares seem to value being given garlands. For example, in the Aulularia, in the prologue of the play, the lar of the family speaks of how much he appreciates the daily gifts from Phaedria, telling us that "she worships [the lar] every single day with incense or wine or something else, and gives [him] garlands." 13 The garland here is singled out as a special object of devotion by Phaedria - and one that the lar seems to appreciate, given its placement in this passage. In the Trinummus, the character Callicles states that he wants to decorate his lar (and presumably his associated shrine) with a garland (Plautus, Trinummus 39).

Our greatest insight into the dedication of garlands to the lares comes from the second-century $\mathrm{BCE}$ text of Cato the Elder, De agricultura. In his discussion of the managing of an agricultural estate, Cato enumerates the tasks of the vilicus, the male farm manager, and the vilica, the female farm manager. Cato indicates that one of the vilica's most important tasks is to make offerings to the lares: "on the kalends, the ides, the nones (of each month), and when there is a religious holiday, she should hang a garland on the hearth and should make requests to the household lar on those days, (accompanied by other offerings) according to her means."14 Above all other offerings for the lares, garlands are singled out here-and at least three times a month, the vilica should give garlands, meaning at least 36 garlands over the course of a year (Flower 2017, pp. 43-45).

While the evidence of Plautus and Cato is early, later literary and material evidence indicate that garlands were indeed an important part of the religious devotion of the lares. In Augustus' reorganization of the neighborhoods of Rome in $7 \mathrm{BCE}$, local crossroad shrines were dedicated to the lares Augusti and the genius Augusti. ${ }^{15}$ As part of these reforms, in addition to the Compitalia (celebrated in early January), we know that garlands were to be given at least twice a year, in the spring and summer (perhaps on 1 May and 27 June, respectively); and these dates have been argued by some to

13 Plautus, Aulularia 23-25, trans. H.I. Flower. Ea mihi cottidie aut ture aut vino aut aliqui semper supplicat, dat mihi coronas. For a full discussion of this passage, see: (Flower 2017, pp. 31-35).

14 Cato, de Agricultura 143, trans. H.I. Flower. Kalendis, idibus, nonis, festus dies cum erit, coronam in focum indat, per eosdemque dies lari familiari pro copia supplicet. For a full discussion of this passage, see: (Flower 2017, pp. 40-45).

15 (Lott 2010, pp. 81-127; Flower 2017, pp. 255-347). Flower asserts that these shrines were not in fact dedicated to the lares Augusti; for more on this argument, see: (Flower 2017, pp. 299-312). 
be founded on ancient holidays associated with long-since-worshipped lares (e.g., lares Praestites). ${ }^{16}$ Regardless, it becomes apparent that lares were honored in the streets and crossroads with flowers at various times throughout the year; thus demonstrating the importance of flower offerings to the lares in pubic settings in particular. Whether or not the compital shrines of Pompeii were dedicated to the lares Augusti (and thus followed religious practice of the city of Rome), it is clear that the lares in the streets of Pompeii would have also received flower dedications at certain times of the year, as we will see below. ${ }^{17}$ As such, in addition to the painted garlands on the walls of Pompeii, in sacrifice scenes associated with the lares, we often see attendants carrying garlands along with their sacrificial accoutrement, indicating the important use of garlands in the veneration of the lares (Laforge 2009, p. 215). Finally, with the promulgation of the Theodosian Code in 392 CE, pre-Christian Roman religious activities were banned, including venerating "a lar with fire, a genius with pure wine, or offer fragrant smells to family gods (penates); let no one light a lamp (or candle), offer incense, hang up a garland of flowers (serta suspendat)."18 The inclusion of the act of hanging garlands in the final ban of pre-Christian religious activities demonstrates the importance and longevity of this Roman religious practice (particularly regarding the veneration of the lares) until the end of the fourth century, along with its widespread use.

\section{Physical Evidence for Hanging Garlands on Roman Walls}

Painted walls in Pompeii that depicted religious scenes are often framed by floral garlands. ${ }^{19}$ While some paintings have more intricate garlands than others, for the most part the garlands on Pompeian walls are schematically rendered, allowing the viewer to discern easily the makeup of the garlands being used (Figure 1). Most garlands are segmented, hanging down from nails that are also often painted on to the walls (Figure 4). The segments come in a variety of lengths (whether two or three hanging threads) based on the composition of the scene below and the width of the available wall space. Ribbons are usually illustrated dangling from the painted nails, where the garlands hang, adding a festive flair (Figure 5). Along the length of the garlands, flowers are indicated through tight color bunching, as we saw above with the cupids constructing garlands, the mollis serta. The flowers come in an array of colors, including red, yellow, orange, and green, and sometimes color blocking is shown on the garlands, with different segments of the garland shown in one hue followed by a different. On the far ends of the garlands, tail ends hang vertically, providing a frame to the whole composition. Due to the schematic nature of the illustration of the garlands, it can be difficult to discern which flowers are intended by the artist. ${ }^{20}$ The crowded composition, however, reminds us of the garlands being constructed by cupids above that might have been made of roses and/or violets. Naturally, we do not know the exact design or materials of the physical garlands that were placed on top of these painted versions. In all likelihood the hanging floral garlands were made from flowers (and other vegetation) that were available seasonally.

16 Suetonius, Augustus 31.4. See also: (Lott 2010, pp. 115-17; Flower 2017, pp. 273-74, 339). Ovid also reports that a temple associated with the lares in Rome was often venerated with garlands (Fasti 6.792).

17 For more on whether or not urban centers outside of Rome renamed their neighborhood lares to align with Rome, see: (Van Andriga 2000, pp. 78-80; Flower 2017, p. 345).

18 Theod. Cod. 16.10.12 pr., trans. H.I. Flower. For a discussion of this passage, see: (Flower 2017, pp. 348-51).

19 While there are countless painted garlands on the walls of Pompeii, it is beyond the scope of the present paper to address evidence for physical hanging garlands outside of religious images.

20 Not all painted garlands were rendered schematically; there are examples of detailed garlands on the painted surfaces of Pompeii. For example, the famous image of the god Dionysus in front of Mount Vesuvius from the Casa del Centenario (9.8.3-6) includes a finely rendered garland, with discernable roses and green leaves. The panel was part of a larger lararium shrine, with lares and a niche. See: (Fröhlich 1991, cat. no. L107; Giacobello 2008, cat. no. 108). 


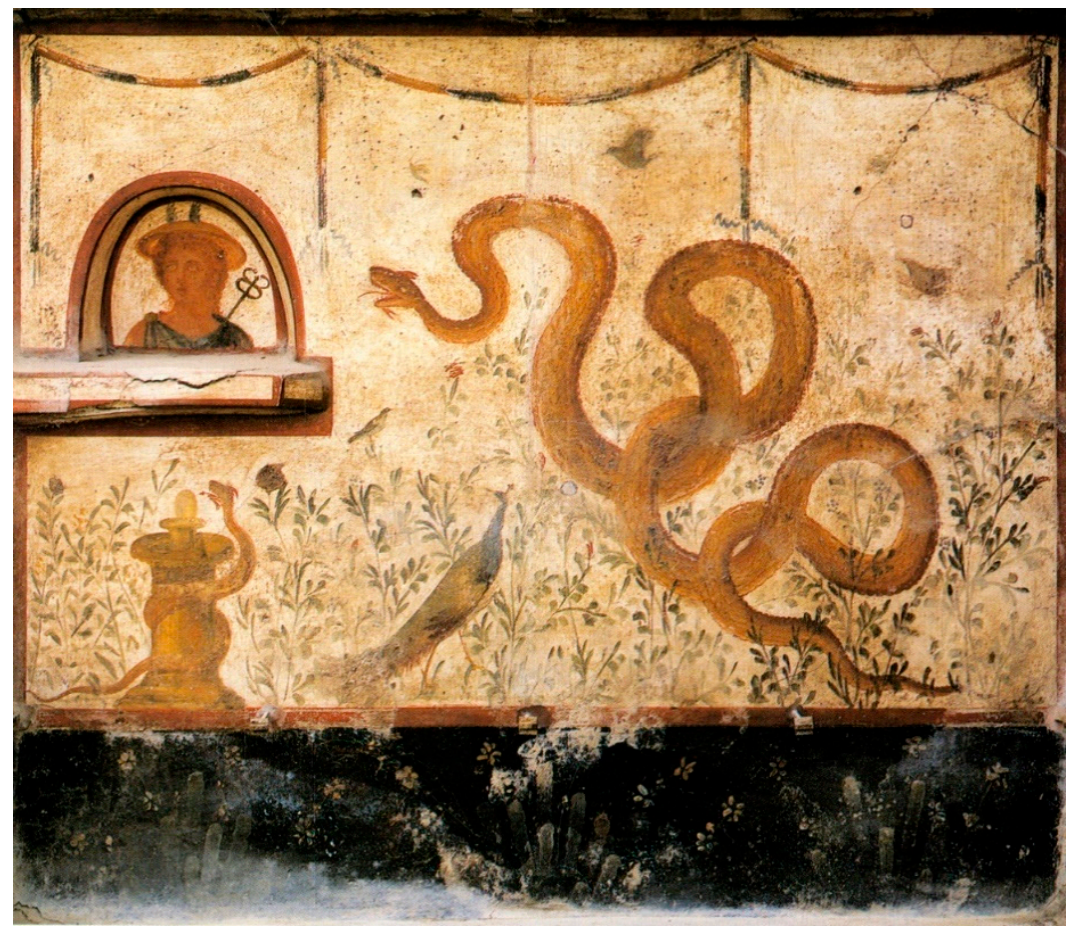

Figure 4. Casa del Criptoportico (1.6.2), Pompeii. Nails on painted garland at top of composition. (Modified by author, after Fröhlich 1991, Taf. 2.2).

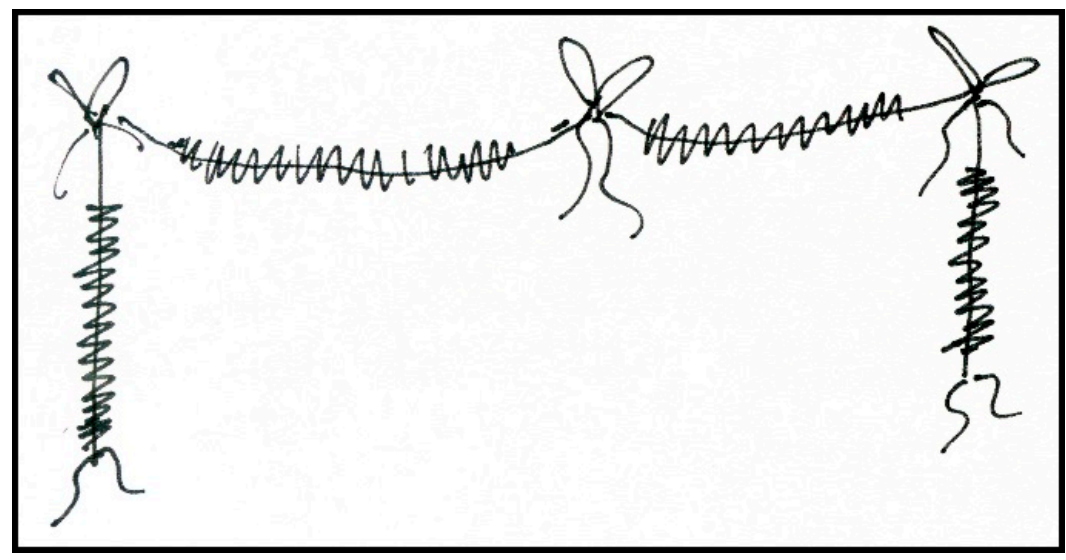

Figure 5. Drawing of hanging garland (Drawing by author).

It is possible, however, to reconstruct the act of hanging garlands on walls in relation to holes left in the plaster-or by the presence of iron nails still extant in the walls. ${ }^{21}$ It should be noted at the onset that nails could support a variety of objects, including fabrics, ribbons, garlands, and potentially even shelves. Surveying the modern scholarship to date, it seems that there has been only scant attention paid to evidence of the phenomenon of using nails to hang garlands over painted garlands. ${ }^{22}$ In this study, seven examples of painted garlands with evidence for nail holes are presented, along with two examples of nails in domestic religious spaces (without painted garlands). Of our seven examples, two appear in kitchens, three in commercial spaces, one in a latrine of a public bath, and one at a

21 On Roman nail types, see: (Manning 1985, pp.134-37; Dungworth 1998).

22 For example, Boyce, in his corpus of lararia in Pompeii only mentions three examples (Boyce 1937, cat nos. 213, 349, 459). Flower does have passing mentions of the evidence of nails as indicators of religious practice around these painted spaces (e.g., Flower 2017, p. 75). 
crossroads shrine. The present study relied on evidence of this practice in the volumes of the Pompei: Pitture e mosaici (1990-2003). While a survey of the photographs of the volumes presented a number of possible candidates for nail holes atop painted garlands, only the seven examples discussed below were chosen for the current study, as they clearly indicate the mimetic practice in question here; further field research on the ground in Pompeii would certainly find more cases of this phenomenon. While only a few examples are presented here, we should imagine a more widespread practice of hanging garlands for several reasons. In many cases, the current preservation of many of the walls does not provide the upper register of the painted compositions, which would indicate holes for nails or nails themselves. Subsequent to initial excavation, holes for nails in the wall plaster may have been repaired by modern conservators, making it difficult for us to present a full catalogue of all the examples of this practice in Pompeii (see a potential example below, pp. 14-15). In the ensuing discussion of our nine examples, it is clear that the practice of mimetic votive of the physical garland atop a painted garland is ubiquitous throughout Pompeii, impacting domestic, commercial, and public streets-thus stressing the extent of this practice. It will be noted that most of the painted walls in this discussion are of the fourth Pompeian painting style, particularly popular after the earthquake of 62 CE (Flower 2017, p. 53).

Oftentimes, evidence for the hanging of floral garlands in domestic spaces can be found in kitchen areas. As we have already seen, there are strong connections with religious paintings in kitchens, particularly showing veneration of the lares, due to the proximity to the household hearth. In the Casa dei Capitelli Colorati (7.4.31/51), in the underground kitchen (59) on the east wall, we find a panel with a snake approaching an altar built into the wall, surrounded by shrubs and red flowers (Figure 6; Boyce 1937, cat. no. 278; Fröhlich 1991, cat. no. L86; Giacobello 2008, cat. no. 79; PPM 6.996-1107). Above the snake is a garland segmented into two parts. At the crests of the segments, there are small holes that allowed for the insertion of nails to hang garlands directly atop the painted garlands, illustrating the interplay between the two- and three-dimensional aspects of the kitchen. While the painting is fragmentary, the holes are surviving manifestations of lived religion, perhaps in this instance on the part of those cooking for the household.

At the Casa del Maiale (9.9.b-c), on the north and west walls of the kitchen (o), there is a scene related to the lares directly next to the stove (Figure 7; Boyce 1937, cat. no. 468; Fröhlich 1991, cat. no. L108; Kastenmeier 2007, pp. 76-79; Giacobello 2008, cat. no. 111; Flower 2017, p. 61). The central panel portrays two brightly-colored lares, flanking a circular altar with a snake, surrounded by laurel trees. Directly below the lares appears the typical appearance of two snakes approaching a circular altar. To the right of the lares, and immediately above the hearth, are pork products associated with sacrificial acts related to the lares (Flower 2017, pp. 55-58). In a fragmentary state, to the left of the lares, is a genius. Directly above the lares is a three-segmented garland of red and yellow, with tails hanging down at the end of the composition. The wall painting is only preserved up to the edge of the frame above the garlands, but there are semicircular depressions in the preserved plaster at exactly the points where each segment of the painted garlands is hung. Thus, we should assume that these depressions in antiquity were spots where nails were hung to allow for draping of garlands in this room.

Commercial spaces in Pompeii also had wall paintings that included religious compositions and were subject to religious veneration. ${ }^{23}$ The Caupona di Soterius (1.12.3) includes a lararium scene on the west wall of its kitchen (k), similar in composition to those we just saw in domestic contexts (Figure 8; Fröhlich, cat. no. L24). Above the lares, again there is a two-segmented garland, which alternates in red and yellow color blocks, along with large ribbons where the garland hangs. At exactly these points along the garland, there are three holes for hanging a garland. In addition, holes survive at the feet of the lares, just above the snakes, suggesting either an anchor for a garland or a support for a shelf hung over the painting (Fröhlich 1991, p. 255).

23 For more on depictions of the lares in commercial spaces, see: (Ellis 2018, pp. 240-43). 


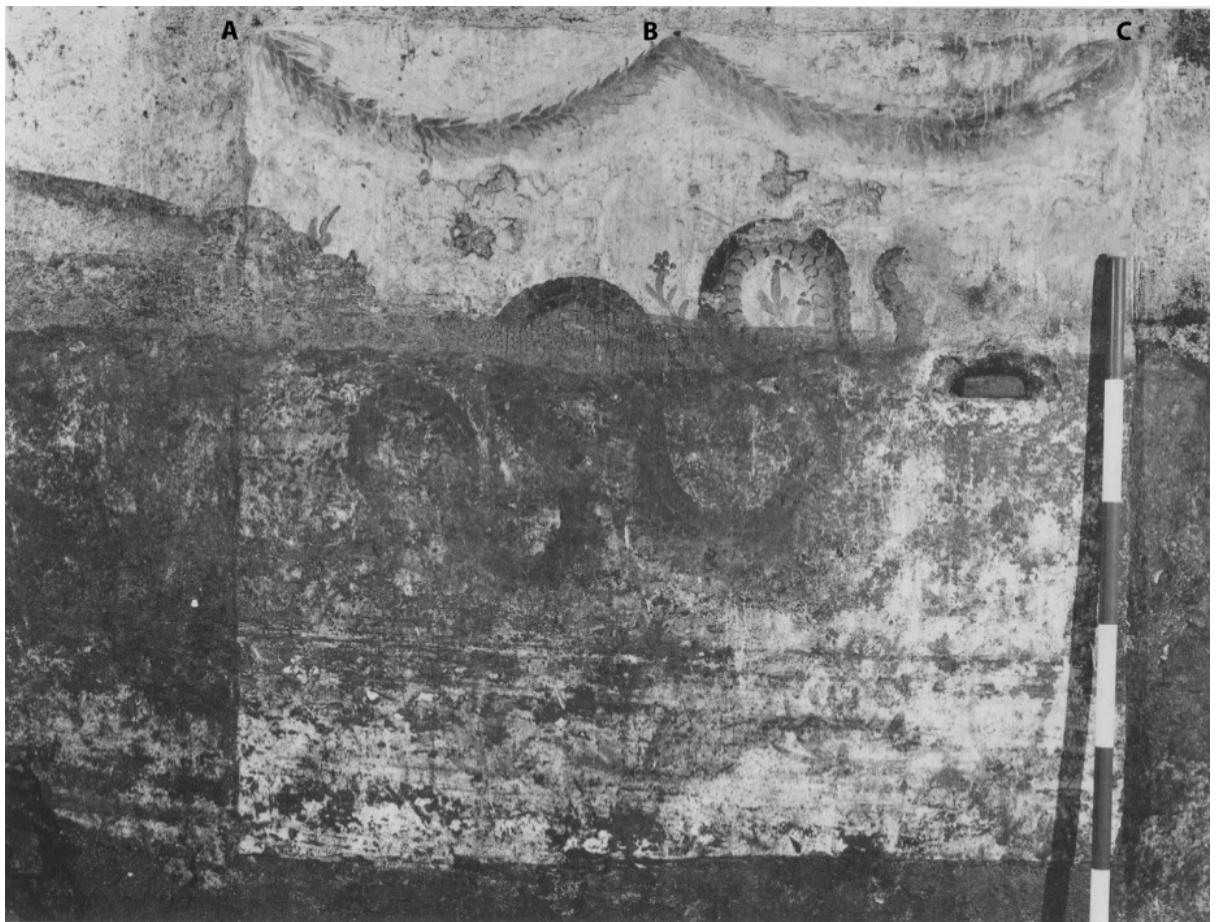

Figure 6. Casa dei Capitelli Colorati (7.4.31.51), Pompeii. Snake approaching an altar. Indications for hanging garlands shown by letters (A-C). (Modified by author, after PPM 7.1107).

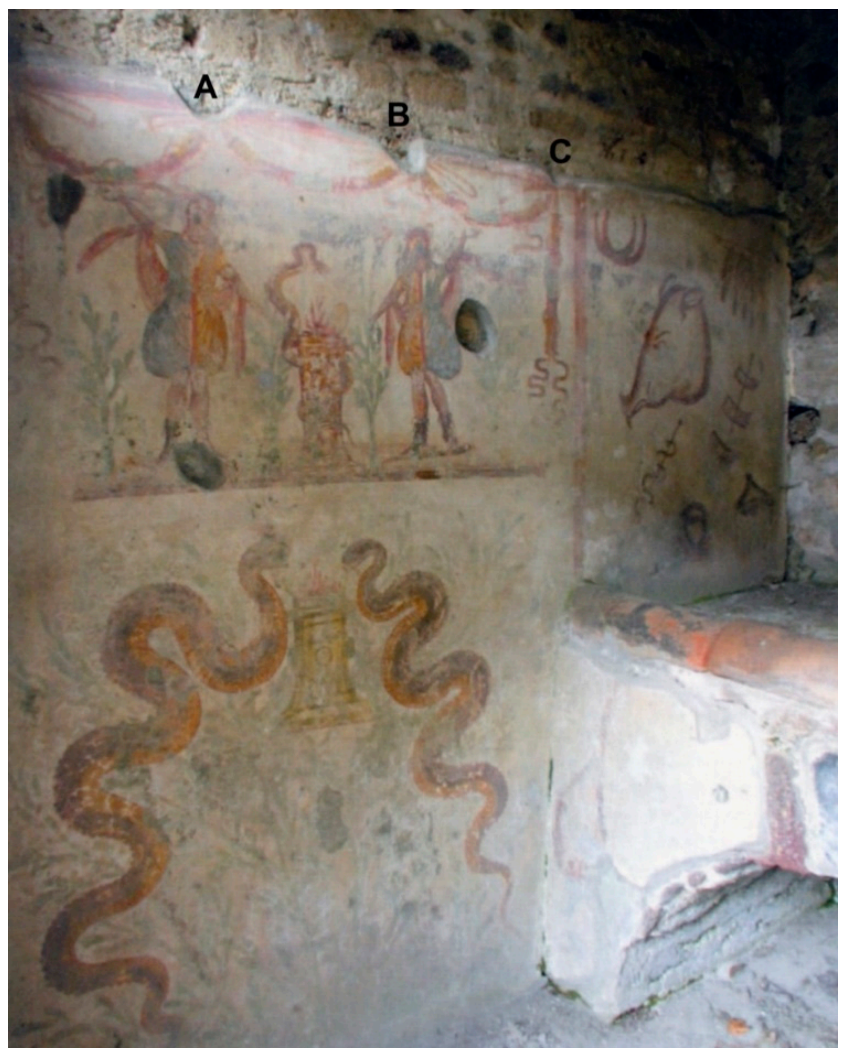

Figure 7. Casa del Maiale (9.9.b-c), Pompeii. Lararium located next to hearth of kitchen (k), with a scene of lares around an altar, above two circles approaching an altar. Pork products associated with a sacrifice to the lares on far right. Indications for hanging garlands shown by letters (A-C). (Modified by author, after Kastenmeier 2007, Figure 55). 


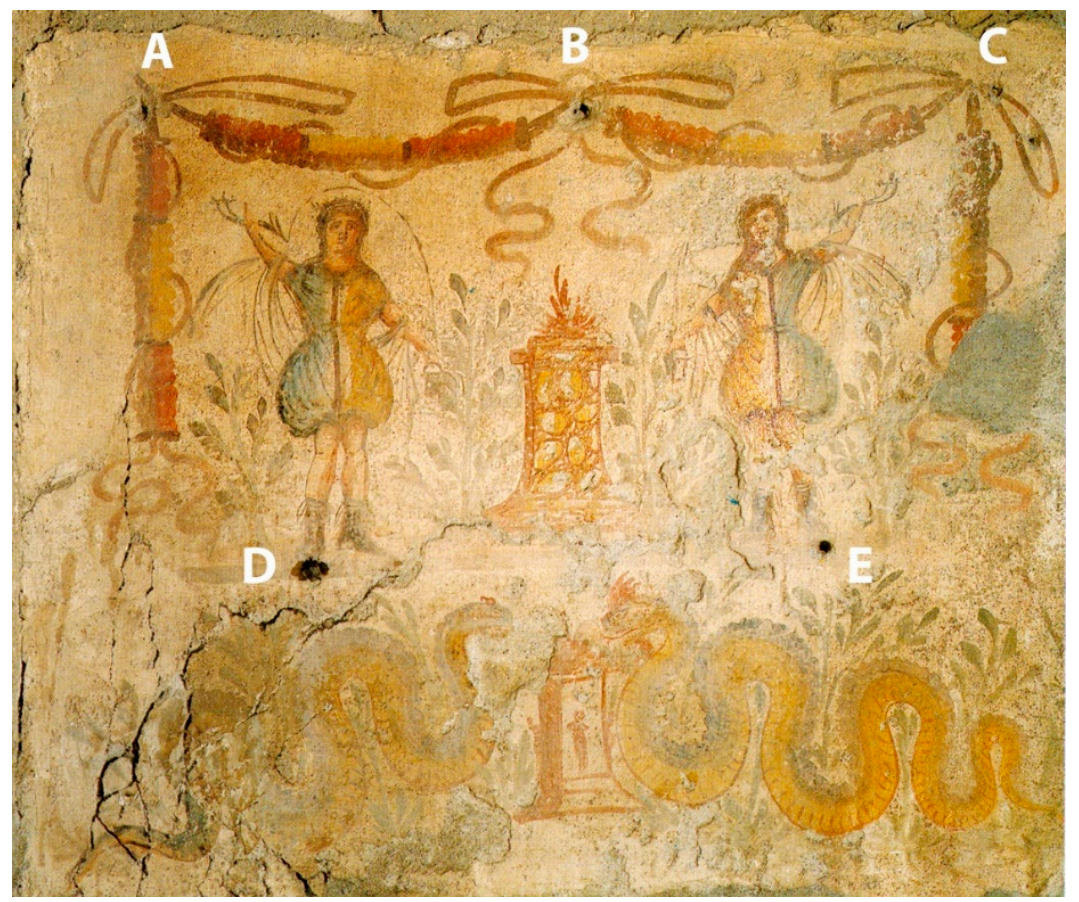

Figure 8. Caupona di Soterius (1.12.3), Pompeii. Two lares flank a circular altar, with two snakes below approaching another altar. Three holes for hanging a garland on the top register are indicated by letters (A-C); two holes for hanging a separate garland below or a shelf are indicated by letters $(\mathbf{D}, \mathbf{E})$. (Modified by author, after Fröhlich 1991, Taf. 4.2).

Other retail spaces include, in addition to the lares, deities attested at Pompeii that are also connected to prosperity. In one bakery (7.12.11), there is another similar composition on the west wall of room $d$, in a finely-rendered style compared to some of the other examples that we have seen (Figure 9; Boyce 1937, cat. no. 316; Fröhlich 1991, cat. no. L91; Giacobello 2008, p. 118). Above the snakes approaching the circular altar, two lares flank an enthroned figure of Vesta, the patron goddess of bakers and bakeries (Giacobello 2008, p. 118). Vesta, wearing a yellow chiton and red mantle, holds a cornucopia in her left arm and tips over a patera over the hearth in front of her, while a donkey pokes his head from behind her throne. On the wall above Vesta and the lares is a two-segmented garland of alternating color blocks of green and yellow. Again, at the points where the painted garlands 'hang' on the wall, we find indications of nail holes used for the hanging of actual floral garlands.

One of the most iconic retail spaces of Pompeii is the Caupona of Lucius Vetutius Placidus (1.8.8) on the via dell'Abbondanza (Figure 10; Fröhlich 1991, cat. no. L8; Giacobello 2008, p. 117). Behind the table counter is an elegant lararium, decorated in fine stucco pediment, engaged columns, and tendrils, along with an upper register showing deities, with the traditional two snakes flanking a circular altar below. The main register depicts two lares flanking a genius, holding a cornucopia and pouring a libation, with Bacchus and a panther on the right, and Mercury holding a money-bag on the left. Above the deities, we find a two-segmented garland with alternating green and yellow color blocks, held up with painted nails. Directly above the garland, outside of the panel, are three corresponding holes for the nails needed to hang up garlands. ${ }^{24}$ It is easy to imagine, then, how shop owners venerated the various deities shown pictorially on their walls with hanging garlands, guided in their acts by those very same images.

24 By comparing photographs of the lararium over time, we discern that at some point in the twentieth century, the holes for the nails were covered with plaster. Compare, for example: (Fröhlich 1991, Taf. 2.1; Giacobello 2008, fig. 17). 


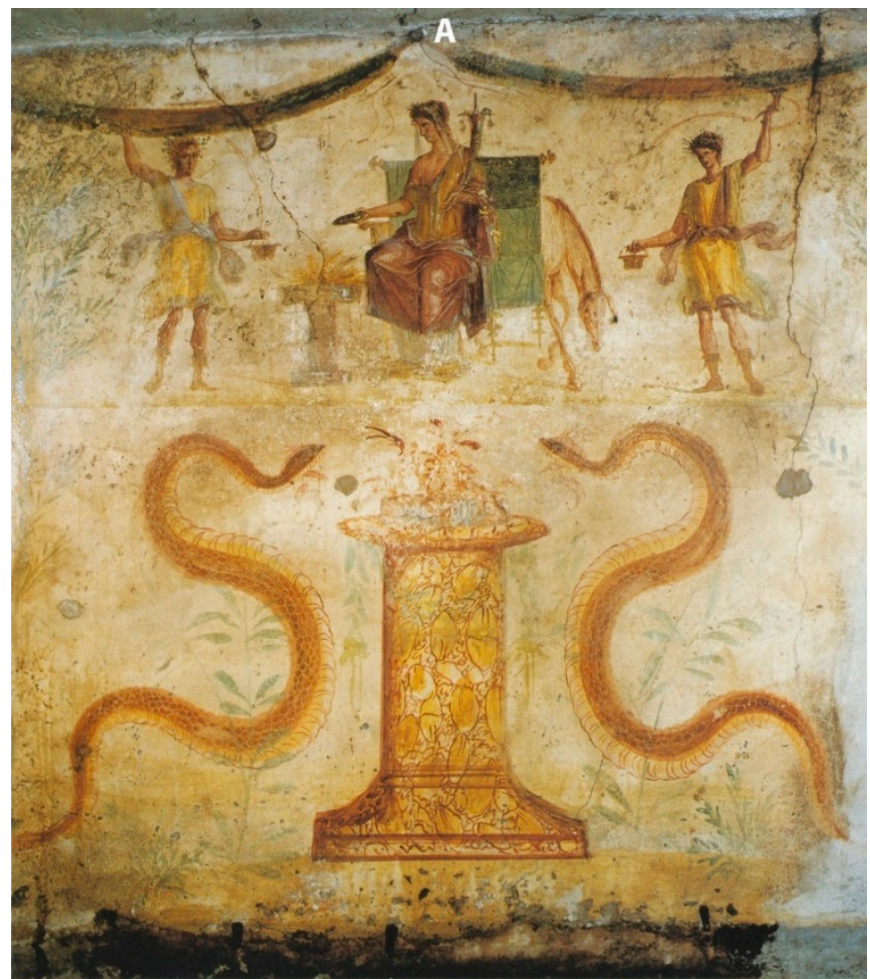

Figure 9. Bakery (7.12.11), Pompeii. Lararium with Vesta, lares, and snakes approaching an altar. Central hole for garland indicated by letter (A). (Modified by author, after Fröhlich 1991, Taf. 1).

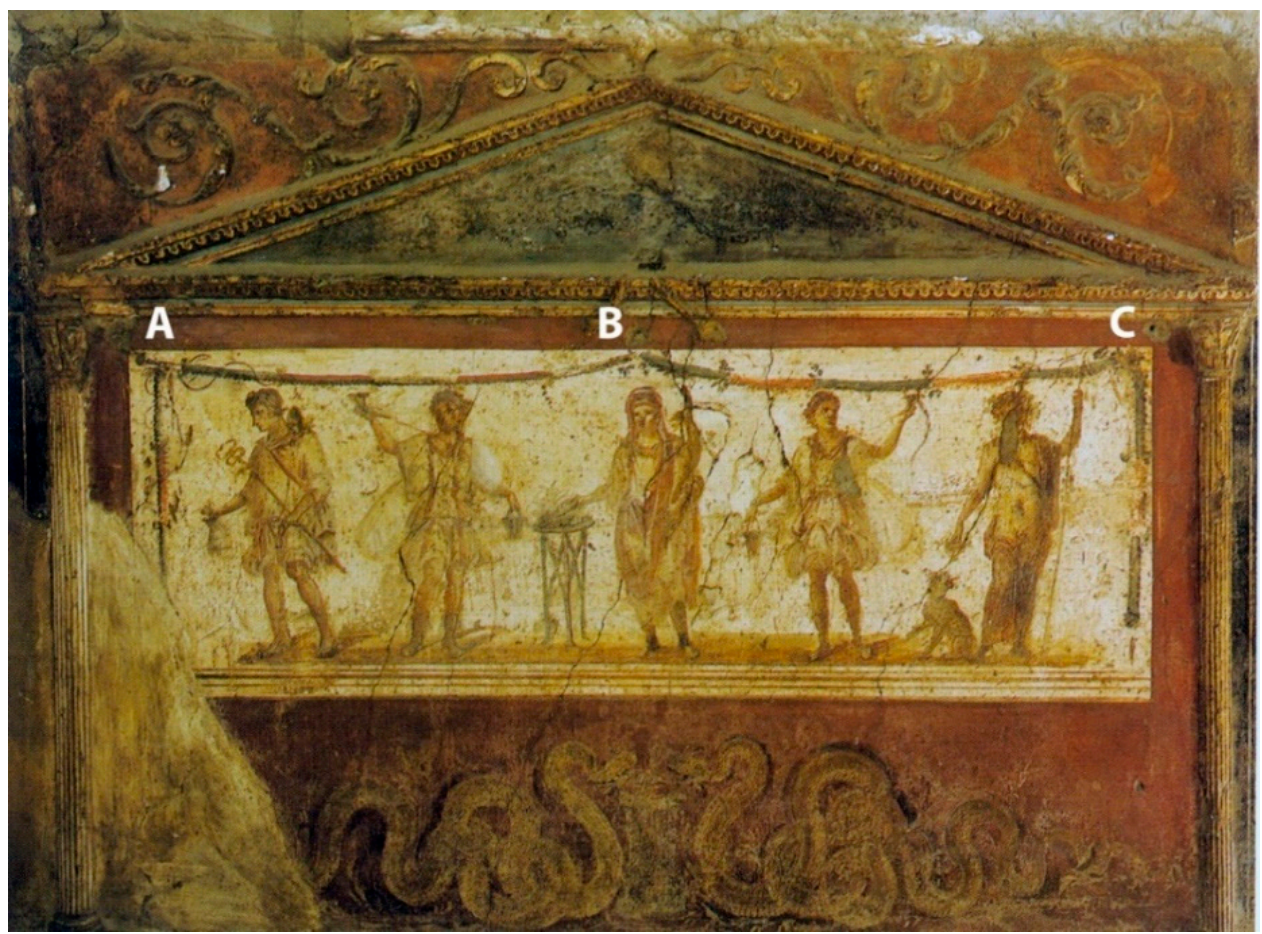

Figure 10. Caupona of Lucius Vetutius Placidus (1.8.8), Pompeii. Upper register includes a genius, flanked by two lares, with Mercury on the far left and Bacchus on the far right. Three holes to hang garlands indicated by letters (A-C). (Modified by author, after Fröhlich 1991, Taf. 2.1).

Latrines also reveal scenes of hanging garlands on their walls. As mentioned above, Romans desired protection in public toilets for a variety of reasons. Tertullian mentions that brothels and latrines should 
receive garlands for acts of religious veneration (De corona militis 13.8; Thüry 2011, p. 44). Further, we find evidence of this religious practice in the toilets (14) of the Suburban Baths of Pompeii (7.16.a), where there is a depiction of Fortuna (Figure 11; Fröhlich 1991, cat. no. L114; Jansen 2011, p. 168; Koloski-Ostrow 2015, pp. 113-14). Situated on the east wall near the entrance, this scene faces toilet users, and it is situated directly above a water basin. Fortuna holds a cornucopia and a rudder, as she stands next to a circular altar. Above her is a two-segmented garland, with red flowers. Above the garland, at its two ends, are two holes to allow for hanging a small garland. Unlike in other examples already noted with three holes, the two holes here suggest smaller garlands being used, perhaps indicative of the constrained space of the latrine. Visitors to the space upon arrival were reminded by the painted garlands that the goddess could be honored with their own mimetic act. In addition to the act of veneration using votive garlands, certainly fresh flowers would also help eradicate bad smells in the space (Koloski-Ostrow 2015, p. 114).

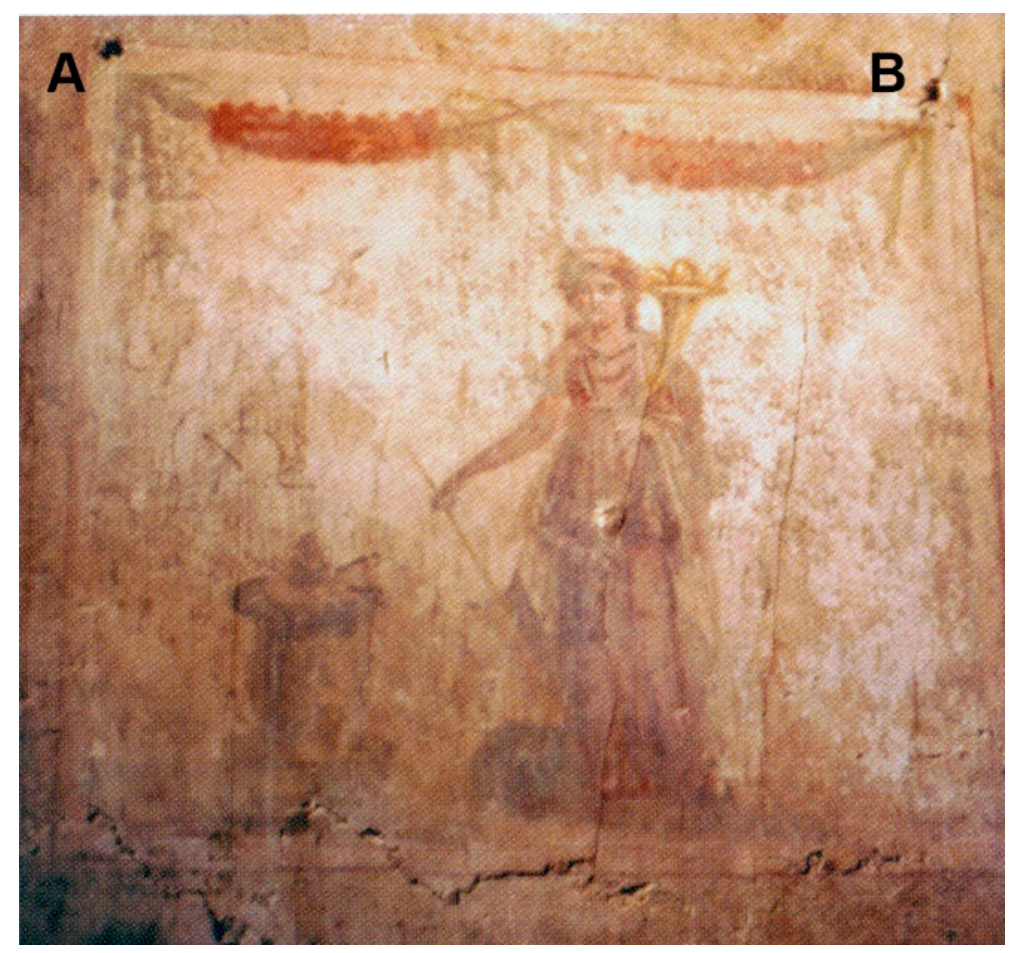

Figure 11. Suburban Baths (7.16.a), Pompeii. Fortuna with cornucopia and rudder, standing in front of an altar. Two holes for garlands indicated by letters (A,B). (Modified by author, after Jansen 2011, Figure 12.7).

On the streets of Pompeii, painted shrines around crossroads also provide evidence for hanging garlands. ${ }^{25}$ On the façade associated with a shop, a caupona (1.11.1), we find a typical shrine of the lares, with two large lares flanking a circular altar, encircled by a snake (Figure 12; Fröhlich 1991, cat. no. F7; Van Andriga 2000, cat. no. 17; Giacobello 2008, pp. 106-7). The painted scene is framed by a two-segmented garland. While the plaster above the scene is not well preserved, it appears that there might be a hole in the wall above the garland to allow someone to hang a garland directly on top of the painted garland. As mentioned above, regarding the city of Rome, the cult of the lares Augusti received garlands on their compital shrines at least twice a year. It is not difficult to imagine then that in Pompeii the local lares received similar dedications throughout the year, especially during the spring and summer, as in Rome. Further evidence of religious activity is demonstrated here through 
the masonry altar situated directly below the painted circular altar. Early excavation photos show the burnt offerings still on the altar-illustrating the devotional activity that once took place there at the time of the eruption of 79. Thus, in this particular example, various types of religious offerings are in evidence at the shrine but are also reinforced by the ever-present painted backdrop.

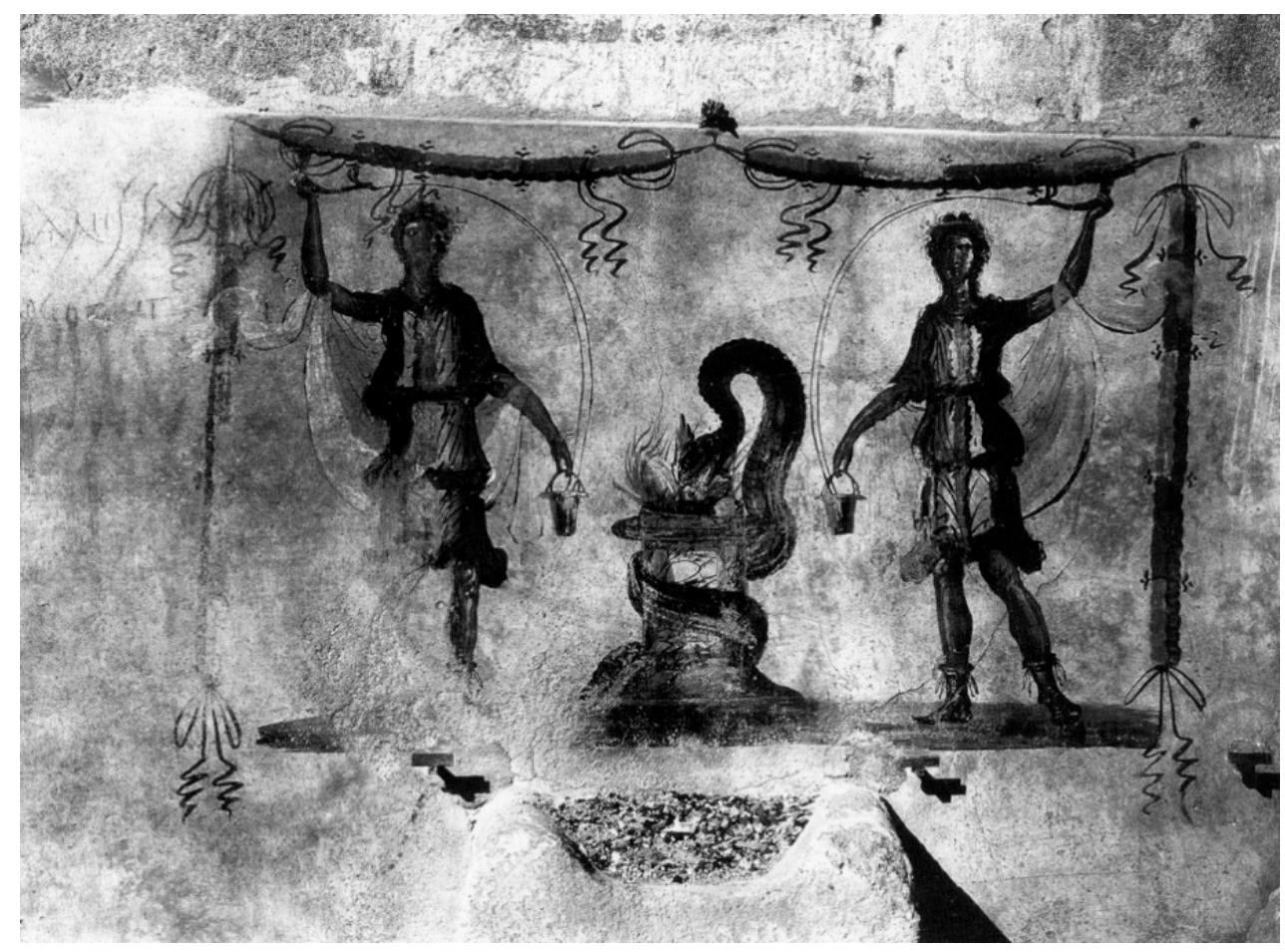

Figure 12. Façade associated with house number 1.11.1, Pompeii. Two lares flank a circular altar, with a snake. A masonry altar with offerings still atop at the bottom. (Modified by author, after Fröhlich 1991, Taf. 53.1).

Finally, even when painted floral garlands do not appear in association with Pompeian structures, there can still be physical evidence on the walls themselves to suggest religious practice. One such example, in the Casa del Menandro (1.10.4), in room 25 on the west wall, above an offering table, is a niche with busts that are often associated with the ancestors of the home, or the imagines maiorum (Boyce 1937, cat. no. 49; Ling and Ling 2005, p. 240; Giacobello 2008, pp. 71-72, cat. no. V12). Two nails above the niche (now removed) indicate that a garland was sometimes hung over the busts (Figure 13). Such an act of worship could be associated with the rites associated with the Parentalia, which occurred in late February, and allowed households to honor the dead ancestors with garlands, cakes, and wine (Ovid, Fasti 2.533-46; Beard et al. 1998, p. 50). Another example of garland hanging is in the sacellum of the atrium of house 1.16.3 (Fröhlich 1991, cat. no. L35; Giacobello 2008, cat. no. A6). The two-pedimented shrine contains painted images of Minerva and a genius offering libations on its walls (Figure 14). Subsequent to its excavation, the shrine's superstructure was reconstructed. A photograph taken at excavation shows two nails above the figure of Minerva, suggesting that garlands could be hung inside the shrine. Although the nails have since been removed, their presence suggests the hanging of physical garlands in various spaces, and more evidence for lived religion at Pompeii. 


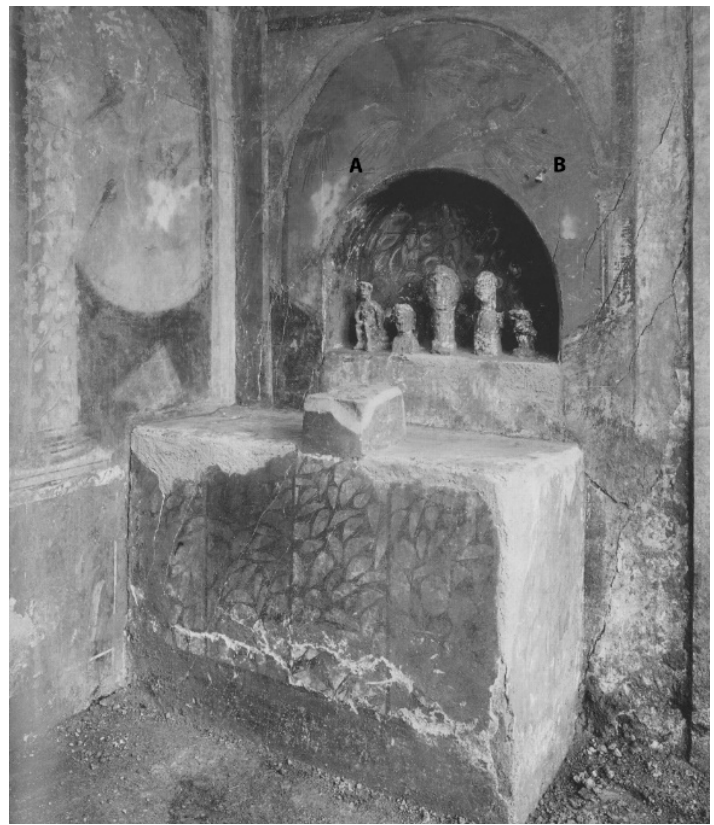

Figure 13. Casa del Menandro (1.10.4), Pompeii. Room 25, with niche containing busts of ancestors. Indications for garlands shown by letters (A,B). (Modified by author, after PPM 2.373).
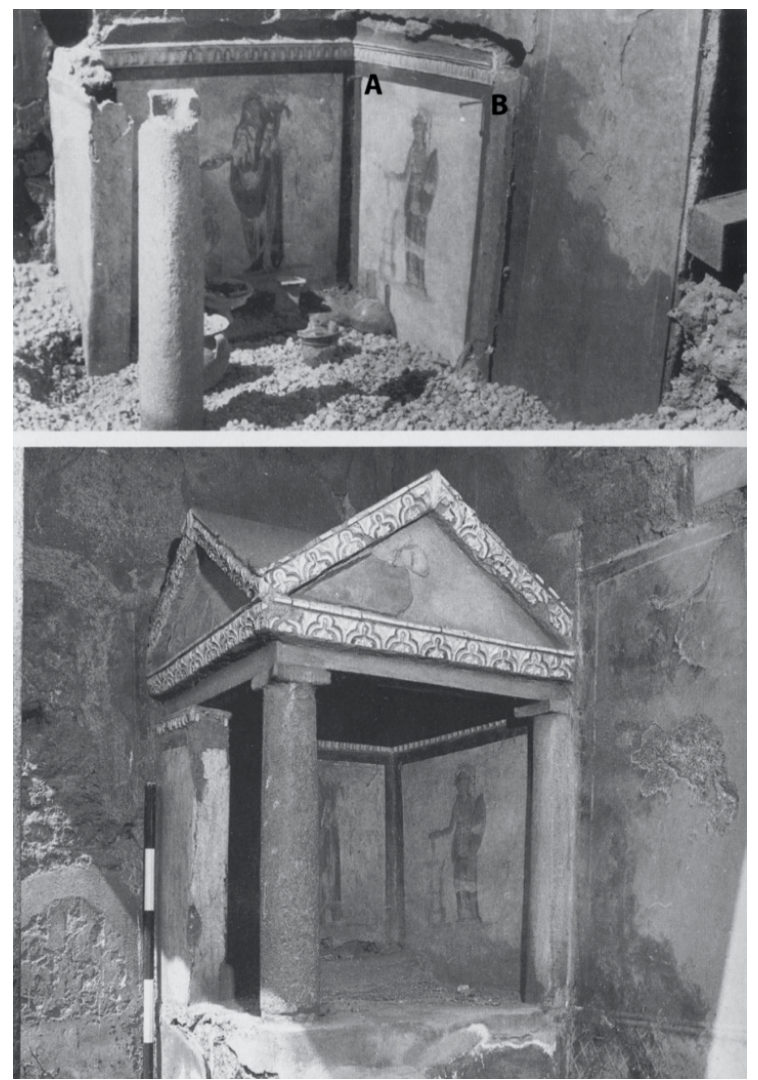

Figure 14. House 1.16.3, Pompeii. Atrium with sacellum. Above, an excavation photograph with nails above Minerva, indicated by letters (A,B). Below, a recent photograph with nails removed. (Modified by author, after PPM 2.988). 


\section{Conclusions}

The painted garlands on the walls of Pompeii indicate lived religious practice. For the most part, the pictorial garlands are schematic renderings of floral garlands-only the most important elements are included, such as vibrant colors, ribbons, and nails. The Romans, however, were proud of their ability to achieve mimesis, or the imitation of life in the painted form, as is evident in the writings of Vitruvius (for example, De architectura 7.5.1-2; Elsner 1995, pp. 53-55; Morales 1996). According to Pliny, painters were not able to capture the true color combinations of flowers (Naturalis historia 21.9); this may be one explanation for why the garlands in question are stylized color-blocks that merely suggest real florals to the viewer yet would have been instantly recognizable objects. The inclusion of painted garlands on walls is an enduring reminder to individuals and the community that garland-giving is a vital part of the veneration of the deities depicted in that space. In a sense, the painted garlands acted as a road map for expected religious devotion.

The painted garlands at Pompeii, then, are a continual fixture in these spaces and, as already said above, part of the pictorial act of lived religion. The act of veneration broke the barrier between the two-dimensional painted surface and the three-dimensional physical space that the Pompeiians inhabited. The natural and artificial worlds intersected to create a unique experience, in which the people of Pompeii offered devotion to their deities, be it with an ephemeral garland or a painted one. The permanency of painted garlands categorized them as mimetic votives, while various deities, including the lares, were constantly being venerated with flowers through mimetic acts. No matter the time of the year, the painted garlands were perpetually in full bloom, defying the constraints of the seasonality of real garlands, as well as their inevitable fate to wilt and wither.

The underlying concern in each of the contexts explored, both public and private, is predicated on communicating with tutelary deities, in order to gain some sort of protection. Examples from domestic spaces have helped to illustrate the desire to protect all members of the family, thus tying the whole familial unit together. At commercial properties, garland-giving would have had the ability to ensure prosperity. Shrines in the street not only provided protection to nearby inhabitants, but also allowed those individuals to have a shared experience, tying them together in a similar fashion to religious activities occurring in a domestic setting. Finally, fortune and luck were given in latrines to those offering garlands-ensuring the protection of Fortuna. The practice of illustrating garlands and offering the infrastructure to affix physical examples in a variety of public and private contexts, in these spaces and on their surfaces, points to a shared religious prerogative among the inhabitants of the city of Pompeii.

This brief examination of the interplay between two- and three-dimensional garlands in the excavated properties of Pompeii has wider implications for the study of ancient religious activity at the site. We saw in the example of the street side shrine how, in a similar vein, built altars could not only receive material offerings, but also could have painted offerings on their surfaces. Pompeii's unique state of preservation affords the opportunity to uncover additional pieces of evidence and encourages us to look elsewhere in the Roman word for related examples. The perpetuated actions of lived religion can be expressed through the material world, the built environment, and the painted (or sculpted) surface. ${ }^{26}$ Particularly through exposing mimetic acts of devotion, we come to a better understanding of how spaces were used in antiquity, especially in terms of the daily experiences associated with lived religion.

Funding: This research received no external funding.

26 Indeed, one only need to think of sculpted garlands on Roman altars. One of the most famous examples is on the upper registers of the interior of the Ara Pacis Augustae in Rome, with large floral garlands hanging in-between bucrania. There is also evidence on some Roman sacrificial altars for appendiges carved into the stone that allowed worhippers to affix physical garlands on the altar itself (Bowerman 1913, p. 77; Honroth 1971). 
Acknowledgments: I would sincerely like to thank Tyler Jo Smith and Carrie Sulosky Weaver for reading various drafts of this article-and providing such helpful advice along the way. I also want to thank Elizabeth Molacek for always discussing various aspects of Roman painting with me, helping to refine my thoughts for this article. Thanks are owed to Daniel Ehnbom for discussing floral offerings in Buddhist art. Finally, I appreciate the thoughtful comments and feedback of the editors of this special issue, Regina Gee and Vanessa Rousseau, along with the anonymous reviewers, all of which substantially improved this article. All errors remain my own.

Conflicts of Interest: The author declares no conflict of interest.

\section{Abbreviations}

CIL Corpus Inscriptionum Latinarum.

LIMC Lexicon Iconographicum Mythologiae Classicae. 1981-2009. Zurich: Artemis.

PPM Carratelli, Giovanni Pugliese, Ida Baldassarre. 1990-2003. Pompei: Pitture e mosaici. Rome:

ThesCRA Balty, Jean-Charles, 2004-present. Thesaurus Cultus et Rituum Antiquorum. Los Angeles: J. Paul Getty Museum Press.

\section{References}

Albrecht, Janico, Christopher Degelmann, Valentino Gasparini, Richard Gordon, Maik Patzelt, Georgia Petridou, Rubina Raja, Anna-Katharina Rieger, Jörg Rüpke, Benjamin Sippel, and et al. 2018. Religion in the Making: The Lived Ancient Religion Approach. Religion 48.3: 568-93. [CrossRef]

Barnabei, Lorenza. 2007. I culti di Pompei. Raccolta critica della documentazione. In Contributi de Archeologia Vesuviana III. Rome: “L'Erma” di Bretschneider, pp. 7-88.

Bassani, Maddalena. 2008. Sacraria: Ambienti e Piccolo Edifice per il Culto Domestico in Area Vesuviana. Rome: Edizioni Quasar, vol. 9.

Bassani, Maddalena. 2017. Sacra Privata Nell'italia Centrale: Archeologia, Fonti Letterarie e Documenti Epigrafici. Rome: Edizioni Quasar, vol. 40.

Bassani, Maddalena, and Francesca Ghedini, eds. 2011. Religionem Significare: Aspetti Storico-Religiosi, Sturtturali, Iconografici e Materiali dei Sacra Privata. Rome: Edizioni Quasar, vol. 19.

Beard, Mary, John North, and Simon Price. 1998. Religions of Rome, Volume 1: A History. Cambridge: Cambridge University Press.

Belayche, Nicole. 2007. Religious Actors in Daily Life. In A Companion to Roman Religion. Edited by Jörg Rüpke. Malden: Blackwell, pp. 275-91.

Bowerman, Helen Cox. 1913. Roman Sacrificial Altars: An Archaeological Study of Monuments in Rome. Ph.D. dissertation, Bryn Mawr College, Pennsylvania, PA, USA.

Bowes, Kimberly. 2015. At Home. In A Companion to the Archaeology of Religion in the Ancient World. Edited by Rubina Raja and Jörg Rüpke. Chichester: Wiley Blackwell, pp. 209-19.

Boyce, George. 1937. Corpus of the Lararia of Pompeii. Memoirs of the American Academy in Rome. Rome: American Academy in Rome, vol. 14.

D'Alessio, Maria Teresa. 2009. I Culti di Pompei: Divinità, Luoghi e Frequentatori (VI secolo a.C.-79 d.C.). Rome: Libreria dello Stato.

Dungworth, David. 1998. Mystifying Roman Nails: Clavus Annalis, Defixiones, and Minkisi. In TRAC 97: Proceedings of the Seventh Annual Theoretical Roman Archaeology Conference, Nottingham 1997. Edited by Colin Forcey, John Hawthorne and Robert Witcher. Oxford: Oxbow Books, pp. 148-59. [CrossRef]

Ellis, Steven. 2018. The Roman Retail Revolution: The Socio-Economic World of the Taberna. Oxford: Oxford University Press.

Elsner, Jaś. 1995. Art and the Roman Viewer: The Transformation of Art from the Pagan World to Christianity. Cambridge: Cambridge University Press.

Elsner, Jaś. 2007. Roman Eyes: Visuality \& Subjectivity in Art \& Text. Princeton: Princeton University Press.

Flower, Harriet. 2017. The Dancing Lares and the Serpent in the Garden: Religion at the Roman Street Corner. Princeton: Princeton University Press.

Foss, Pedar. 1997. Watchful Lares: Roman Household Organization and the Rituals of Cooking and Eating. In Domestic Space in the Roman World: Pompeii and Beyond. Edited by Ray Laurence and Andrew Wallace-Hadrill. Portsmouth: British Academy, pp. 197-218. 
Fröhlich, Thomas. 1991. Lararien- und Fassadenbilder in den Vesuvstädten: Untersuchungen zur 'volkstümlichen' Pompejanischen Malerei. Mainz: Verlag Philipp von Zabern.

Gasparini, Valentino, Maik Patzelt, Rubina Raja, Anna-Katharina Rieger, Jörg Rüpke, and Emiliano Urciuoli, eds. 2020. Lived Religion in the Ancient Mediterranean World: Approaching Religious Transformations from Archaeology, History, and Classics. Berlin: De Gruyter. [CrossRef]

Giacobello, Federica. 2008. Larari Pompeiani: Iconografia e Culto dei Lari in Ambito Domestico. Milan: Edizioni Universitarie di Lettere Economia Diretto.

Guillaume-Coirier, Germaine. 1995. Images du coronarius dans la littérature et l'art de Rome. Mélanges de l'École Française de Rome, Antiquité 107: 1093-151. [CrossRef]

Guillaume-Coirier, Germaine. 1999. L'ars coronaria dans la Rome antique. Revue Archéologique 2: 331-70.

Guillaume-Coirier, Germaine. 2002. Techniques coronaires romaines: Plantes "liées" et plantes "enfilées". Revue Archéologique 1: 61-71. [CrossRef]

Hartnett, Jeremy. 2017. The Roman Street: Urban Life and Society in Pompeii, Herculaneum, and Rome. Cambridge: Cambridge University Press.

Honroth, Margret. 1971. Stadtrömische Girlanden: Ein Versuch zur Entwicklungsgeschichte römischer Ornamentik. Vienna: Im Selbstverlag.

Jansen, Gemma C. M. 2011. Cultural Attitudes. In Roman Toilets: Their Archaeology and Cultural History. Edited by Gemma C.M. Jansen, Ann Olga Koloski-Ostrow and Eric M. Moormann. Babesch Supplement 19. Leuven: Peeters, pp. 165-76.

Jashemski, Wilhelmina. 2018. Produce Gardens. In Gardens of the Roman Empire. Edited by Wilhelmina F. Jashemski, Kathyrn L. Gleason, Kim J. Hartswick and Amina-Aïcha Malek. Cambridge: Cambridge University Press, pp. 121-51.

Kastenmeier, Pia. 2007. I Luoghi del Lavoro Domestic Nella Casa Pompeiana. Rome: “L'Erma” di Bretschneider.

Kaufmann-Heinimann, Annemarie. 2007. Religion in the House. In A Companion to Roman Religion. Edited by Jörg Rüpke. Malden: Blackwell, pp. 188-201.

Koloski-Ostrow, Ann Olga. 2015. The Archaeology of Sanitation in Roman Italy: Toilets, Sewers, and Water Systems. Chapel Hill: University of North Carolina Press.

Laforge, Marie-Odile. 2009. La Religion Privée à Pompéi. Naples: Centre Jean Bérard.

Lerner, Martin, and Steven Kossak. 1991. The Lotus Transcendent: Indian and Southeast Asian Art from the Samuel Eilenberg Collection. New York: Metropolitan Museum of Art.

Ling, Roger, and Lesley Ling. 2005. The Insula of the Menander at Pompeii: Volume II-The Decorations. Oxford: Clarendon Press.

Lott, J. Bert. 2010. The Neighborhoods of Augustan Rome. Cambridge: Cambridge University Press.

MacRae, Duncan E. 2019. Mercury and Materialsm: Images of Mercury and the Tabernae of Pompeii. In Tracking Hermes, Pursuing Mercury. Edited by John F. Miller and Jenny Strauss Clay. Oxford: Oxford University Press, pp. 193-208.

Manning, William H. 1985. Catalogue of the Romano-British Iron Tools, Fittings, and Weapons in the British Museum. London: British Museum Publications.

Morales, Helen. 1996. The Torturer's Apprentice: Parrhasius and the Limits of Art. In Art and Text in Roman Culture. Edited by Jaś Elsner. Cambridge: Cambridge University Press, pp. 182-209.

Orr, David. 1978. Roman Domestic Religion: The Evidence of the Household Shrines. Aufstieg und Niedergang der Römischen Welt 16: 1557-91.

Raja, Rubina, and Jörg Rüpke, eds. 2015. Archaeology of Religion, Material Religion, and the Ancient World. In $A$ Companion to the Archaeology of Religion in the Ancient World. Chichester: Wiley Blackwell, pp. 1-26.

Rogers, Dylan Kelby. 2018. Water Culture in Roman Society. Leiden: Brill. [CrossRef]

Rüpke, Jörg. 2011. Lived Ancient Religion: Questioning “Cults" and "Polis Religion”. Mythos 5: 191-203.

Rüpke, Jörg. 2015. Individual Choices and Individuality in the Archaeology of Ancient Religion. In A Companion to the Archaeology of Religion in the Ancient World. Edited by Rubina Raja and Jörg Rüpke. Chichester: Wiley Blackwell, pp. 437-50.

Rüpke, Jörg. 2018. Pantheon: A New History of Roman Religion. Translated by David M. B. Richardson. Princeton: Princeton University Press.

Rüpke, Jörg, and Christopher Degelmann. 2015. Narratives as a Lens into Lived Ancient Religion, Individual Agency and Collective Identity. Religion in the Roman Empire 1: 289-96. [CrossRef] 
Swetnam-Burland, M. 2018. Material Evidence and the Isiac Cults: Art and Experience in the Sanctuary. In Individuals and Materials in the Greco-Roman Cults of Isis: Agents, Images, and Practices. Edited by Valentino Gasparini and Richard Veymiers. Leiden: Brill, Religions in the Graeco-Roman World, vol. 187, pp. 584-608. [CrossRef]

Thüry, Günther E. 2011. Das römische Latrinenwesen im Spiegel der litterarischen Zeugnisse. In Roman Toilets: Their Archaeology and Cultural History. Edited by Gemma C.M. Jansen, Ann Olga Koloski-Ostrow and Eric M. Moormann. Babesch Supplement 19. Leuven: Peeters, pp. 43-47.

Turcan, Robert. 1971. Les guirlandes dans l'antiquité classique. Jahrbuch für Antike und Christentum 14: 92-139.

Van Andriga, William. 2000. Autels de Carrefour, organization vicinale et rapports de voisinage à Pompéi. Rivista di Studi Pompeiani 11: 47-86.

Van Andriga, William. 2009. Quotidien des Dieux et des Hommes: La vie Religieuse Dans les Cites du Vésuve à L'époque Romaine. Rome: École française de Rome.

Weiss, Lara. 2015a. Perpetuated Action. In A Companion to the Archaeology of Religion in the Ancient World. Edited by Rubina Raja and Jörg Rüpke. Chichester: Wiley Blackwell, pp. 60-70.

Weiss, Lara. 2015b. Religious Practice at Deir el-Medina. Leuven: Peeters.

(C) 2020 by the author. Licensee MDPI, Basel, Switzerland. This article is an open access article distributed under the terms and conditions of the Creative Commons Attribution (CC BY) license (http://creativecommons.org/licenses/by/4.0/). 